\title{
SMC1A wt Allele
}

National Cancer Institute

\section{Source}

National Cancer Institute. SMC1A wt Allele. NCI Thesaurus. Code C75407.

Human SMC1A wild-type allele is located within Xp11.22-p11.21 and is approximately 49 $\mathrm{kb}$ in length. This allele, which encodes Structural Maintenance of Chromosomes Protein $1 \mathrm{~A}$, is involved in the maintenance of cohesion of sister chromatids during mitosis.

Mutations in this gene are associated with Cornelia de Lange syndrome. 